\title{
RELATIVE FEEDING SPECIALIZATION MAY DEPRESS ONTOGENETIC, SEASONAL, AND SEXUAL VARIATIONS IN DIET: THE ENDEMIC LIZARD Cnemidophorus littoralis (TEIIDAE)
}

\author{
TEIXEIRA-FILHO, P. F., ${ }^{1}$ ROCHA, C. F. D. ${ }^{2}$ and RIBAS, S. C. ${ }^{1}$ \\ ${ }^{1}$ Setor de Zoologia, Instituto de Biologia Roberto Alcântara Gomes, Universidade do \\ Estado do Rio de Janeiro, Rio de Janeiro, RJ, Brazil \\ ${ }^{2}$ Setor de Ecologia, Instituto de Biologia Roberto Alcântara Gomes, Universidade do \\ Estado do Rio de Janeiro, Rio de Janeiro, RJ, Brazil \\ Correspondence to: Carlos Frederico D. Rocha, Setor de Ecologia, Instituto de Biologia Roberto Alcântara Gomes, \\ Universidade do Estado do Rio de Janeiro, Rua Francisco Xavier, 524, Maracanã, CEP 20559-900, Rio de Janeiro, \\ RJ, Brazil, e-mail: cfdrocha@uerj.br \\ Received December 4, 2001 - Accepted Juny 7, 2002 - Distributed May 31, 2003
}

(With 1 figure)

\begin{abstract}
We investigated the feeding habits of the teiid lizard Cnemidophorus littoralis in the markedly seasonal

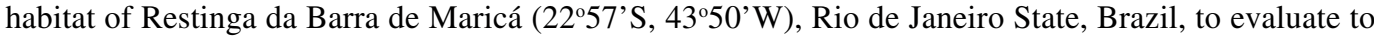
what extent its diet is ontogenetically, sexually, and/or seasonally conservative. Lizard stomach contents were analyzed, identified, counted, estimated for volume (in $\mathrm{mm}^{3}$ ), and grouped in four classes (active, sedentary, and clumped preys, and plant material). The relative contribution of each food class to the total prey volume consumed by adult males and females and juveniles was compared in three ways: between juveniles and adults, sexes, and seasons (wet and dry). Sexual dimorphism in head size was tested by comparing head width and jaw length using analysis of covariance (ANCOVA). Isopterans were the most important prey item, occurring in $93 \%$ of the lizard stomachs examined and corresponding to $96.4 \%$ of total prey content and $69.7 \%$ of total prey volume. They occurred in high frequencies in the stomachs of $C$. littoralis throughout all study months. We found no sexual, ontogenetic, or seasonal differences in $C$. littoralis diet although the sexes differed significantly in head width. We concluded that isopterans are the main item in the diet of $C$. littoralis in Restinga da Barra de Maricá, both for juveniles and adults. The lack of seasonal, sexual, or ontogenetic variation in its diet results from the massive consumption of these insects. Isopterans are small, occur in clumps, and are available year-round, and thus are an advantageous food item for the active forager $C$. littoralis. We also found sexual dimorphism in the head size of $C$. littoralis: males have wider heads than females. This dimorphism, however, does not seem to be related with the diet of the species, and is probably a result of sexual selection.
\end{abstract}

Key words: lizard, Teiidae, restinga, conservative diet, sexual dimorphism.

\section{RESUMO}

Especialização relativa alimentar pode reduzir variações ontogenéticas, sexuais e sazonais na dieta: o lagarto Cnemidophorus littoralis (Teiidae)

Estudamos a dieta do lagarto teídeo Cnemidophorus littoralis no ambiente sazonal da Restinga da Barra de Maricá (2257’S, 4350’W), Estado do Rio de Janeiro, Brasil, analisando em que extensão a dieta 
do lagarto é sexual, ontogenética e/ou sazonalmente conservativa. O conteúdo do estômago dos lagartos foi analisado, identificado, contado, estimado seu volume e agrupado em quatro classes (presas ativas, sedentárias, distribuídas de forma agregada e material vegetal). A contribuição relativa de cada tipo de presa para o número e volume total consumido por adultos machos e fêmeas e para jovens foi comparada entre jovens e adultos, entre os sexos e entre as estações (seca e úmida). O dimorfismo sexual no tamanho da cabeça foi testado comparando a largura da cabeça e o comprimento da mandíbula por análise de covariância (ANCOVA). Os isópteros foram as presas mais importantes, ocorrendo nos estômagos de 93\% dos lagartos e correspondendo a $96,4 \%$ do número total de presas e a $69,7 \%$ do volume total das presas, apresentando altas freqüências nos estômagos em todos os meses do ano. Não houve diferenças sexuais, ontogenéticas ou sazonais na dieta de $C$. littoralis, embora os sexos tenham diferido significativamente na largura da cabeça. Portanto, concluímos que isópteros constituem o principal item da dieta de $C$. littoralis na Restinga da Barra de Maricá, tanto para jovens quanto para adultos, e que a ausência de variação sazonal, ontogenética ou sexual na dieta da espécie resulta do elevado consumo desses insetos. Os isópteros são pequenos, ocorrem agrupados e estão disponíveis ao longo de todo o ano, constituindo item alimentar vantajoso para o forrageador ativo $C$. littoralis. O dimorfismo sexual no tamanho da cabeça (machos com cabeças mais largas) parece não estar relacionado à dieta da espécie, sendo provavelmente resultado da seleção sexual.

Palavras-chave: lagarto, Teiidae, restinga, dieta conservativa, dimorfismo sexual.

\section{INTRODUCTION}

Many lizard species show a relationship between the size and/or volume of prey items and mouth part sizes (e.g., Schoener, 1967, 1968; Schoener \& Gorman, 1968; Vitt, 1983; Preest, 1994). This relationship may cause differences in type or size of prey consumed along ontogeny, and in diet composition between seasons or between sexes when size differs (Vitt, 1983; Preest, 1994). Large preys represent a total pack with comparatively more energy than small ones, and as a lizard increases in size, larger prey is more advantageous (Toft, 1985; Magnusson \& Silva, 1993), causing ontogenetic shifts in diet composition. Also, because in many lizard species the sexes differ in size, sexual differences in mouth part sizes may result in sexual differences in diet (e.g., Schoener, 1967). In addition, since the environment is continuously changing over time due to variations in climatic conditions, seasonal shifts in diet commonly occur in many lizard species (e.g., Chapman \& Chapman, 1964; Pianka, 1970; Burquez et al., 1986; Maya \& Malone, 1989; Rocha, 1996) because the spectrum and proportions of prey types available in the habitat may also change seasonally. However, if a particular lizard species maintains high consumption of a small-sized prey available throughout the year, these expected tendencies should not develop, resulting in little or no ontogenetic, seasonal, or sexual dietary differences (Vrcibradic \& Rocha, 1998; Vrcibradic et al., 1998; Zaluar \& Rocha, 2000).

Cnemidophorus littoralis is a teiid lizard presently considered an endemic species of the restinga habitats of the Rio de Janeiro State coast in southeastern Brazil (Rocha et al., 2000). This species has been previously referred to as $C$. ocellifer by many authors (e.g., Araújo, 1984, 1991; Rocha, 1994; Ribas et al., 1995; Teixeira-Filho et al., 1995), but was recently described as a new species by Rocha et al. (2000). It is a heliothermic lizard with a mean body temperature in activity of $38.7 \pm 2.0^{\circ} \mathrm{C}$ at the Restinga da Barra de Maricá (Teixeira-Filho et al., 1995). It forages mainly along shrub edges and is usually active from 8:00 to $15: 00$ $\mathrm{h}$ with an activity peak between 10:00 and 12:00 h (Teixeira-Filho et al., 1995; Hatano et al., 2001).

In general, isopterans constitute a considerable portion of the diet of both juveniles and adults of Cnemidophorus lizards (Vanzolini et al., 1980; Vitt, 1991, 1995; Bergallo \& Rocha, 1994). Because these lizards are relatively selective towards a particular type of small-sized prey (isopterans) which is available yearlong in Barra de Maricá (Vallejo \& Vallejo, 1981), we would expect that common tendencies regarding ontogenetic, seasonal, or sexual differences in diet composition, or relationship 
between mean prey size and mouth part sizes described above, would be weak or non-existent in $C$. littoralis at this restinga. In this study we investigate the food habits of $C$. littoralis in a markedly seasonal habitat to evaluate if its diet is sexually, ontogenetically, and/or seasonally conservative.

\section{MATERIAL AND METHODS}

\section{Study area}

The study was carried out at the Restinga da

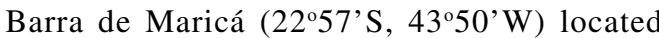
approximately $38 \mathrm{~km}$ east of the city of Rio de Janeiro. Restingas are salt-sandy strips covered with herbaceous and shrubby vegetation. These habitats originated in the Quaternary (Suguio \& Tessler, 1984), and are common along the Brazilian coast. The climate of the study area is wet and warm with seasonal change in mean temperature and rainfall (Franco et al., 1984). A warm and rainy period occurs from December to March and a dry one from May to September (Franco et al., 1984; Rocha, 1992). Mean annual temperature varies between 22 and $24^{\circ} \mathrm{C}$, and mean annual rainfall from 1000 to $1350 \mathrm{~mm}$ (Nimer, 1972, 1979).

Using an air rifle, we collected sixty-nine animals from October 1988 to September 1989. Lizards were weighed (to the nearest $0.2 \mathrm{~g}$ ) using a Pesola ${ }^{\circledR}$ spring balance and fixed in the field with $10 \%$ formalin. For each individual we measured (using a vernier caliper, to the nearest $0.1 \mathrm{~mm}$ ) the snout-vent length (SVL), head width (HW, measured at the point of maximum head width) and jaw length (JL, measured from snout to mouth commissure).

Lizards were dissected, sexed, and were analyzed for stomach contents. Prey items were identified, counted, and measured to the nearest $0.1 \mathrm{~mm}$ for length, width, and depth with a vernier caliper. The volume in $\mathrm{mm}^{3}$ of each individual prey was estimated by multiplying its three dimensions (Schoener, 1967). The relationship between lizard morphometric variables and mean and maximum length in $\mathrm{mm}$ and volume in $\mathrm{mm}^{3}$ of preys, and with prey number found in the stomach of each lizard was tested using regression analysis (Zar, 1999).
Food types were grouped in four classes, following Bergallo \& Rocha (1994): a) active prey (e.g., hymenopterans, coleopterans, lepidopterans); b) sedentary prey (all larvae); c) clumped prey (termites); and d) plant material. The relative contribution of each food class to the total prey volume consumed by adult males and females and juveniles were compared in three ways: between juveniles and adults, then sexes, and, finally, seasons (wet and dry).

To evaluate the similarity in proportion of prey types consumed according to ontogenetic stages, season, and sexes we used Spearman Rank Correlation (Zar, 1999). Differences in distribution of prey types eaten by adult males and females and by juveniles ( $\mathrm{SVL}<55.0 \mathrm{~mm}$ ) were tested using Kolmogorov-Smirnov two-group test (Zar, 1999). Seasonal differences in diet were analyzed by comparing the diets in the dry (May to September) and wet seasons (October to April).

Sexual dimorphism in head size was tested comparing HW and JL by analysis of covariance (ANCOVA) (Zar, 1999), using SVL as covariate. Means are followed by \pm 1 standard deviation throughout the text.

\section{RESULTS}

Adult males, adult females, and juveniles averaged respectively $66.8 \pm 6.9 \mathrm{~mm}(\mathrm{~N}=24)$, $64.8 \pm 5.1 \mathrm{~mm}(\mathrm{~N}=19)$, and $46.1 \pm 5.0 \mathrm{~mm}(\mathrm{~N}=$ $22)$ in SVL. The mean SVL of adult males and females did not differ significantly (ANOVA, $\mathrm{F}_{1,41}=$ $1.17 ; \mathrm{p}=0.285$ ). Mean HW of adult males averaged $10.4 \pm 1.5 \mathrm{~mm}(\mathrm{~N}=23)$ whereas that of adult females averaged $9.4 \pm 0.8 \mathrm{~mm}(\mathrm{~N}=17)$, with the sexes differing significantly in HW (ANCOVA; $\left.\mathrm{R}^{2}=0.81 ; \mathrm{F}_{1,60}=6.700 ; \mathrm{p}=0.012 ; \mathrm{n}=61\right)$ (Fig. 1). Mean JL of adult males averaged $14.4 \pm 2.6$ $\mathrm{mm}(\mathrm{N}=23)$ whereas that of adult females averaged $13.3 \pm 1.8 \mathrm{~mm}(\mathrm{~N}=18)$, with the sexes not differing significantly in JL (ANCOVA; $\mathrm{F}_{1,60}=1.265 ; \mathrm{p}=$ 0.265).

Of the 69 stomachs examined, two (or 2.9\%) were empty. Isopterans were the most important prey item occurring in $93 \%$ of the lizard stomachs examined, corresponding to $96.4 \%$ of total prey number $(\mathrm{N}=4059)$ and $69.7 \%$ of total prey vo- 
lume $\left(21003.5 \mathrm{~mm}^{3}\right)$ (Table 1$)$. They occurred in high frequencies in the stomachs of $C$. littoralis throughout all study months. The second most important prey item was coleopteran larvae, corresponding to $0.88 \%$ of total prey number, $7.18 \%$ of total prey volume, and occurring in $29 \%$ of the stomachs (Table 1). Spiders were also consumed with relatively high frequency $(20 \%)$, but they comprised only $0.45 \%$ of total number and $0.75 \%$ of total volume (Table 1).

There was no significant variation in the diet of Cnemidophorus littoralis in terms of distribution of prey items among the three populational segments (Kolmogorov-Smirnov; $\mathrm{N}=21$; adult males/juveniles: $\mathrm{D}_{\max }=0.0122 ; \mathrm{p}=0.81 ;$ adult females/juveniles: $\mathrm{D}_{\max }=0.02 ; \mathrm{p}=0.71 ;$ adult males/adult females: $\left.\mathrm{D}_{\text {max }}=0.0179 ; \mathrm{p}=0.64\right)$. Because the population segments of $C$. littoralis did not differ in diet, we pooled the data presented in the overall diet of the species in Table 2. The diet of adult males was significantly correlated with the diet of juveniles $\left(r_{s}=0.50 ; \mathrm{p}<0.05 ; \mathrm{n}=21\right)$ and with that of adult females $\left(\mathrm{r}_{\mathrm{s}}=0.36 ; \mathrm{p}<0.05 ; \mathrm{n}=21\right)$. Correlation between adult females and juveniles was marginally significant $\left(r_{s}=0.36 ; 0.05<p<0.10 ; n=21\right)$.

There was no significant relationship between the number of food items in the stomach and the body dimensions of the lizard (SVL: $\mathrm{N}=69$; $\mathrm{r}=$ $0.08 ; \mathrm{p}=0.53$; HW: $\mathrm{N}=61 ; \mathrm{r}<0.01 ; \mathrm{p}=0.97)$. Furthermore, length and volume of prey did not correlate $(p>0.05)$ with morphometric variables.

\section{DISCUSSION}

Widely-foraging lizards in open habitats tend to eat relatively clumped and/or sedentary prey when compared to sit-and-wait lizard species, which feed on relatively more mobile prey (e.g., Huey \& Pianka, 1981; Magnusson et al., 1985; Bergallo \& Rocha, 1994; Zaluar \& Rocha, 2000). At the Restinga da Barra de Maricá, C. littoralis has the general pattern of wide-foraging behavior typical of the Teiidae family (Pianka, 1970, 1973; Vanzolini et al., 1980; Dunham \& Miles, 1985) and its diet reflects this pattern.

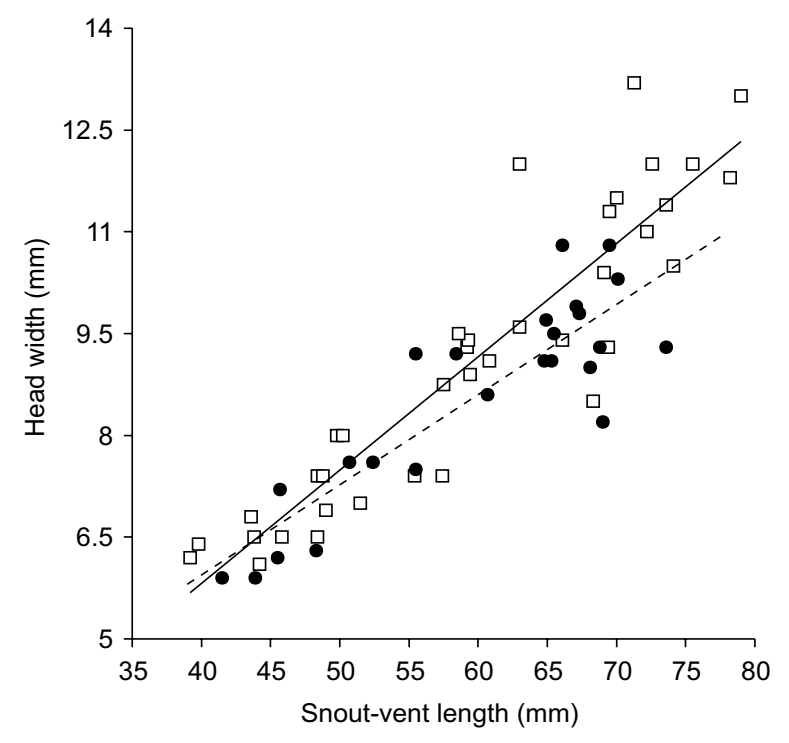

Fig. 1 - Regression of head width (in $\mathrm{mm}$ ) as a function of snout-vent length (in $\mathrm{mm}$ ) of Cnemidophorus littoralis in Barra de Maricá, RJ. Males: open symbols and solid line; females: solid symbols and dotted line. Regression equations are $\mathrm{y}=$ $0.167 \mathrm{x}-0.8621$ (males) and $\mathrm{y}=0.134 \mathrm{x}-0.5461$ (females). 
TABLE 1

Number, volume (in $\mathrm{mm}^{3}$ ) and frequency (F) of each food item in stomachs of Cnemidophorus littoralis $(\mathrm{N}=69)$ at Restinga da Barra de Maricá. Uap = unidentified arthropods parts.

\begin{tabular}{|l|c|c|c|}
\hline \multicolumn{1}{|c|}{ Food item } & Number $(\boldsymbol{\%})$ & Volume (\%) & F (\%) \\
\hline Isoptera & $4059(96.37)$ & $14640.5(69.70)$ & 92.8 \\
\hline Hymenoptera & $5(0.12)$ & $27.7(0.13)$ & 7.2 \\
\hline Plant material & $7(0.17)$ & $299.7(1.43)$ & 7.2 \\
\hline \multicolumn{1}{|c|}{ Flowers } & $3(0.07)$ & $25.6(0.60)$ & 4.5 \\
\hline Fruits & $3(0.07)$ & $173.2(0.82)$ & 2.9 \\
\hline Seeds & $1(0.02)$ & $0.9(<0.01)$ & 1.4 \\
\hline Homoptera & $3(0.07)$ & $20.5(0.10)$ & 4.5 \\
\hline Pseudoscorpionida & $2(0.05)$ & $2.6(0.01)$ & 2.9 \\
\hline Araneae & $19(0.45)$ & $158.5(0.75)$ & 20.3 \\
\hline Collembola & $2(0.05)$ & $16.8(0.08)$ & 1.4 \\
\hline Chilopoda & $2(0.05)$ & $65.2(0.31)$ & 2.9 \\
\hline Orthoptera & $3(0.07)$ & $303.4(1.44)$ & 2.9 \\
\hline Blattaria & $9(0.21)$ & $1926.1(9.17)$ & 10.1 \\
\hline Coleoptera & $4(0.09)$ & $148.5(0.71)$ & 5.8 \\
\hline Coleoptera Larvae & $37(0.89)$ & $1508.1(7.18)$ & 29.0 \\
\hline Lepidoptera Larvae & $14(0.33)$ & $514.9(2.45)$ & 5.8 \\
\hline Diptera Larvae & $2(0.05)$ & $15.5(0.12)$ & 2.9 \\
\hline Other Larvae & $1(0.02)$ & $13.8(0.06)$ & 1.4 \\
\hline Diptera & $1(0.02)$ & $203.7(0.97)$ & 1.4 \\
\hline Hemiptera & $12(0.28)$ & $254.5(1.21)$ & 8.7 \\
\hline Hemiptera Nymphae & $29(0.69)$ & $347.5(1.65)$ & 17.4 \\
\hline Thysanura & $1(0.02)$ & $6.9(0.03)$ & 1.4 \\
\hline Uap & & $529.2(2.52)$ & \\
\hline Total & & $21003.5(100.0)$ & \\
\hline & & & \\
\hline & & $(100.0)$ & \\
\hline
\end{tabular}

Seasonal variations in diet composition of lizards have been reported in several studies from different regions (e.g., Chapman \& Chapman, 1964; Pianka, 1970; Fleming \& Hooker, 1975; Best \& Gennaro, 1984; Burquez et al., 1986; Maya \& Malone, 1989), including in lizard species in the same area (Liolaemus lutzae, Rocha, 1996). These variations have been attributed mainly to seasonal changes in prey availability. Cnemidophorus littoralis in Barra de Maricá showed a different tendency in consuming high frequencies of isopterans throughout all study months, and available yearlong in the area (Vallejo \& Vallejo, 1981). Vitt (1991), who studied some lizard species of Brazilian cerrado, found high isopterans frequencies in the diet of a population of C. ocellifer, and Bergallo \& Rocha (1994) found the same trend for Cnemidophorus nativo in a restinga area of Espírito Santo State in southeastern Brazil. 
TABLE 2

Diet composition by number and volume (in $\mathrm{mm}^{3}$ ) of adult males $(M)$, adult females $(F)$ and juveniles (J) of Cnemidophorus littoralis $(\mathrm{N}=69)$ at Restinga da Barra de Maricá. UAP indicates unidentified arthropods parts.

\begin{tabular}{|c|c|c|c|c|c|c|}
\hline \multirow[t]{2}{*}{ Food type } & \multicolumn{3}{|c|}{ Number } & \multicolumn{3}{|c|}{ Volume } \\
\hline & $\mathbf{M}$ & $\mathbf{F}$ & $\mathbf{J}$ & $\mathbf{M}$ & $\mathbf{F}$ & $\mathbf{J}$ \\
\hline Isoptera & 1411 & 1279 & 1369 & 5660.1 & 5235.8 & 3744.6 \\
\hline Hymenoptera & 3 & - & 2 & 11.1 & - & 16.6 \\
\hline Plant material & 3 & 4 & - & 87.9 & 211.8 & - \\
\hline Flowers & 2 & 1 & - & 87.0 & 38.6 & - \\
\hline Fruits & - & 3 & - & - & 173.2 & - \\
\hline Seeds & 1 & - & - & 0.9 & - & - \\
\hline Homoptera & 1 & - & 2 & 2.8 & - & 17.7 \\
\hline Pseudoscorpionida & - & - & 2 & - & - & 2.6 \\
\hline Araneae & 2 & 6 & 11 & 68.9 & 44.2 & 45.3 \\
\hline Collembola & - & 2 & - & - & 16.8 & - \\
\hline Chilopoda & - & 1 & 1 & - & 60.0 & 5.2 \\
\hline Orthoptera & 2 & 1 & 0 & 149.7 & 153.7 & - \\
\hline Blattaria & 2 & 6 & 1 & 87.9 & 1826.5 & 11.8 \\
\hline Coleoptera & 1 & 3 & - & 31.2 & 117.2 & - \\
\hline Coleoptera Larvae & 23 & 5 & 9 & 1160.2 & 241.6 & 106.3 \\
\hline Lepidoptera Larvae & 1 & 12 & 1 & 89.3 & 407.8 & 17.8 \\
\hline Diptera Larvae & - & 1 & 1 & - & 6.0 & 9.5 \\
\hline Other Larvae & - & - & 1 & - & - & 13.8 \\
\hline Diptera & 1 & - & - & 203.7 & - & - \\
\hline Hemiptera & 2 & 5 & 5 & 18.3 & 170.9 & 65.3 \\
\hline Hemiptera Nymphae & 5 & 4 & 20 & 102.8 & 81.2 & 163.4 \\
\hline Thysanura & - & - & 1 & - & - & 6.9 \\
\hline Uap & & & & 290.0 & 55.6 & 169.8 \\
\hline Total & 1457 & 1329 & 1426 & 7963.9 & 8629.2 & 4396.6 \\
\hline
\end{tabular}

In general, these insects are relatively sedentary prey, with clumped distribution, and are frequent prey items in the diet of wide-foraging lizards, including other Cnemidophorus (Pianka, 1966, 1970, 1986; Huey \& Pianka, 1981; Bergallo \& Rocha, 1994) and teiid species (Ameiva ameiva in Barra de Maricá, Zaluar \& Rocha, 2000).

Vitt (1983) studied some aspects of $C$. ocellifer ecology in the Brazilian caatinga and found sexual differences in mouth dimensions; he suggested that variations in prey consumption could be a consequence of differences in gape size between males and females. Mouth size limits prey consumption, mainly in juvenile lizards (Vitt, 1983). However, the high isopterans frequencies consumed by both male and female $C$. littoralis, and the low frequencies of other food items of both sexes, causes the lack of sexual differences in the diet of this lizard in Barra de Maricá. The absence of correlation between lizard body size (both SVL and HW) and length, number, and volume of prey ingested may result from its high consumption of isopterans. 
Termites are small-sized prey, with reduced size variation, on which both large and small lizards mainly feed. Magnusson \& Silva (1993) in studying the diet of lizards in a community of Alter do Chão, Pará State, Brazil, also found no relationship between lizard size and prey size; lizard diets were more strongly related to their species than to their size. In that study (which includes another Cnemidophorus species, C. lemniscatus), lizard size had little effect on the types of prey consumed, as happens with $C$. littoralis. The aseasonal occurrence of isopterans, as well as its clumped distribution makes them advantageous prey for $C$. littoralis, independent of lizard size. At the Restinga of Barra de Maricá isopterans are abundant throughout the study area, both in termite nests along the sand and among leaf litter in the shrubs. Thus, it is not surprising that isopterans constitute the main food item of both adult and juvenile $C$. littoralis at Barra de Maricá.

Although several studies have related sexual dimorphism in head size with sexual differences in diet composition (e.g., Schoener, 1967, 1968; Schoener \& Gorman, 1968; Preest, 1994), the larger heads of male $C$. littoralis at Barra de Maricá are probably more related to sexual selection since males with larger heads would have some advantage over smaller males during disputes for females and in territorial defense, as suggested by Vitt (1983) for a population of $C$. ocellifer in the Brazilian caatinga. The same relationship has already been described for another teiid (Ameiva ameiva) by Vanzolini et al. (1980) and Zaluar \& Rocha (2000), who suggest that males with bigger jaws have higher reproductive success than those with smaller jaws. This contention seems valid for $C$. littoralis at Barra de Maricá but only additional studies could prove this hypothesis.

We conclude that isopterans are the main item in the diet of $C$. littoralis at Restinga da Barra de Maricá, both for juveniles and adults. The lack of seasonal, sexual, or ontogenetic variation in its diet results from the massive consumption of these insects. Isopterans are small, occur in clumps, and are available throughout the year, thus being an advantageous food item for the active forager $C$. littoralis. We also found sexual dimorphism in head size of $C$. littoralis: males have wider heads than do females. This dimorphism, however, does not seem to be related with the diet of the species and probably is a result of sexual selection.
Acknowledgments - This study is part of the results of the "Programa de Ecologia, Conservação e Manejo de Ecossistemas do Sudeste Brasileiro" and of the Southeastern Brazilian Vertebrate Ecology Project (Vertebrate Ecology Laboratory), both of the Departamento de Ecologia, Instituto de Biologia, Universidade do Estado do Rio de Janeiro. We thank L. N. B. Martins and L. F. Fonseca for field assistance during lizard collection. The graduate and research organ of Rio de Janeiro Sub-reitoria de Pós-graduação e Pesquisa, State University provided many facilities which made the field trips feasible. D. Vrcibradic and M. Van Sluys kindly revised the manuscript and offered helpful suggestions. This study was partially supported by grants from the National Scientific and Technological Development Council (CNPq) to PFTF (process n. 132603/ 93-4), CFDR (300819/94-3 and 461970/00-7) and SCR (135371/ 95-3), and from the Agency for Further Development Graduatelevel (Coordenação de Aperfeiçoamento de Pessoal de Ensino Superior, CAPES) to the third author.

\section{REFERENCES}

ARAÚJO, A. F. B., 1984, Padrões de divisão de recursos em uma comunidade de lagartos de restinga. In: L. D. Lacerda, D. S. D. Araújo, R. Cerqueira \& B. Turcq (eds.), Restingas: origem, estrutura, processos. CEUFF, Niterói, 477: 327-342.

ARAÚJO, A. F. B., 1991, Structure of a white-sand dune lizard community of coastal Brazil. Rev. Bras. Biol., 51(4): 857-865.

BERGALLO, H. G. \& ROCHA, C. F. D., 1994, Spatial and trophic niche differentiation in two sympatric lizards (Tropidurus torquatus and Cnemidophorus ocellifer) with different foraging tactics. Australian Journal of Ecology, 19: 72-75

BEST, T. L. \& GENNARO, A. L., 1984, Feeding ecology of the lizard, Uta stansburiana, in southeastern New Mexico. J. Herpetol., 18: 291-301.

BURQUEZ, A., FLORES-VILLELA, O. \& HERNANDEZ, A., 1986, Herbivory in a small iguanid lizard, Sceloporus torquatus torquatus. J. Herpetol., 20: 262-264.

CHAPMAN, B. M. \& CHAPMAN, F., 1964, Observations on the biology of the lizard Agama agama in Ghana. Proc. Zool. Soc. London, 143: 121-132.

DUNHAM, A. E. \& MILES, D. B., 1985, Patterns of covariation in life history traits of squamate reptiles: the effects of size and phylogeny. Amer. Nat., 126: 231-257.

FLEMING, T. H. \& HOOKER, R. S., 1975, Anolis cupreus: the reponse of a lizard to tropical seasonality. Ecology, 56: 1243-1261.

FRANCO, A. C., VALERIANO, D. M., SANTOS, F. M., HAY, J. D., HENRIQUES, R. P. B. \& MEDEIROS, R. A., 1984, Os microclimas das zonas de vegetação da praia da Restinga da Barra de Maricá, RJ. In: L. D. Lacerda, D. S. D. Araújo, R. Cerqueira \& B. Turcq (eds.), Restingas: origem, estrutura, processos. CEUFF, Niterói, 477: 413-425.

HATANO, F. H., VRCIBRADIC, D., GALDINO, C. A. B. CUNHA-BARROS, M., ROCHA, C. F. D. \& VAN SLUYS M., 2001, Thermal ecology and activity patterns of the lizard community of the restinga of Jurubatiba, Macaé, RJ. Rev. Bras. Biol., 61(2): 287-294. 
HUEY, R. B. \& PIANKA, E. R., 1981, Ecological consequences of foraging mode. Ecology, 62: 991-999.

MAGNUSSON, W. E., DE PAIVA, L. J., DA ROCHA, R. M., FRANKE, C. R., KASPER, L. A. \& LIMA, A. P., 1985, The correlates of foraging mode in a community of Brazilian lizards. Herpetologica, 41: 324-332.

MAGNUSSON, W. E. \& SILVA, E. V., 1993, Relative effects of size season and species on the diets of some Amazonian savanna lizards. J. Herpetol., 27(4): 380-385.

MAYA, J. E. \& MALONE, P., 1989, Feeding habitats and behavior of the whiptail lizard, Cnemidophorus tigris tigris. J. Herpetol., 23(3): 309-311.

NIMER, E., 1972, Climatologia da região Sudeste do Brasil introdução à climatologia dinâmica - subsídios à geografia regional do Brasil. Rev. Bras. Geogr, 34: 3-48.

NIMER, E., 1979, Climatologia do Brasil. IBGE, Rio de Janeiro, 422p.

PIANKA, E. R., 1966, Convexity, desert lizards, and spatial heterogeneity. Ecology, 47: 1055-1059.

PIANKA, E. R., 1970, Comparative autecology of the lizard Cnemidophorus tigris in different parts of its geographic range. Ecology, 51(4): 703-720.

PIANKA, E. R., 1973, The structure of lizard communities. Ann. Rev. Ecol. Syst., 4: 53-74.

PIANKA, E. R., 1986, Ecology and natural history of desert lizards. Princeton Univ. Press., Princeton, New Jersey, 208p.

PREEST, M. R., 1994, Sexual size dimorphism and feeding energetics in Anolis carolinensis: why do females take smaller prey than males? J. Herpe tol., 28(3): 292-294.

RIBAS, S. C., ROCHA, C. F. D., TEIXEIRA-FILHO, P. F. \& VICENTE, J. J., 1995, Helminths (Nematoda) of Cnemidophorus ocellifer (Sauria: Teiidae): assessing the effect of rainfall, lizard body size and sex in the nematode infection rates. Ciência e Cultura, 47: 88-91.

ROCHA, C. F. D., 1992, Ecologia e comportamento de Liolaemus lutzae em uma área de restinga do Sudeste do Brasil. Tese de Doutorado, Dep. Zool., IB, UNICAMP, 180p.

ROCHA, C. F. D., 1994, Introdução à ecologia de lagartos brasileiros. pp. 39-57. In: L. B. Nascimento, A. Bernardes \& G. A. Cotta (eds.), Herpetologia no Brasil, 1. PUC-MG, Belo Horizonte, 134p.

ROCHA, C. F. D., 1996, Seasonal shift in lizard diet: the seasonality in food resources affecting the diet of Liolaemus lutzae (Tropiduridae). Ciência e Cultura, 48: 264-269.

ROCHA, C. F. D., ARAÚJO, A. F. B., VRCIBRADIC, D. \& MAMEDE, E., 2000, New Cnemidophorus (Squamata: Teiidae) from coastal Rio de Janeiro State of Southeast Brazil. Copeia, n. 2, pp. 501-509.
SCHOENER, T. W., 1967, The ecological significance of sexual dimorphism in size in the lizard Anolis conspersus. Science, 155: 474-477.

SCHOENER, T. W., 1968, The Anolis lizards of Bimini: resource partitioning in a complex fauna. Ecology, 49: 704-726.

SCHOENER, T. W. \& GORMAN, G. C., 1968, Some niche differences in three Lesser Antillean lizards of the genus Anolis. Ecology, 49: 819-830.

SUGUIO, K. \& TESSLER, M. G., 1984, Planícies de cordões litorâneos quaternários do Brasil: origem e nomenclatura, pp. 15-25. In: L. D. Lacerda, D. S. D. Araújo, R. Cerqueira \& B. Turcq (eds.), Restingas: origem, estrutura, processos. CEUFF, Niterói, $477 \mathrm{p}$.

TEIXEIRA-FILHO, P. F., ROCHA, C. F. D. \& RIBAS, S. C. 1995, Aspectos da ecologia termal e uso do habitat por Cnemidophorus ocellifer (Sauria: Teiidae) na restinga da Barra de Maricá, pp. 155-165. In: F. A. Esteves (ed.), Oecologia Brasiliensis, v. I - Estrutura, funcionamento e manejo de ecossistemas brasileiros. Rio de Janeiro, UFRJ, 597p.

TOFT, C. A., 1985, Resource partitioning in amphibians and reptiles. Copeia, pp. 1-20.

VALLEJO, L. R. \& VALLEJO, M. S., 1981, Contribuição ao estudo dos microartrópodos do "litter" na restinga de Barra de Maricá, RJ. Rev. Bras. Biol., 41: 535-543.

VANZOLINI, P. E., RAMOS, A. M. M. \& VITT, L. J., 1980, Répteis das caatingas. Acad. Bras. Ciênc. Publ., Rio de Janeiro, 161p.

VITT, L. J., 1983, Reproduction and sexual dimorphism in the tropical teiid lizard Cnemidophorus ocellifer. Copeia, 2: 359-366.

VITT, L. J., 1991, An introduction to the ecology of Cerrado lizards. J. Herpetol., 25(1): 79-90.

VITT, L. J., 1995, The ecology of tropical lizards in the caatinga of Northeast Brazil. Occ Pap. Okla. Mus. Nat. Hist., 1: 1-29.

VRCIBRADIC, D. \& ROCHA, C. F. D., 1998, The ecology of the skink Mabuya frenata in an area of rock outcrops in Southeastern Brazil. Journal of Herpetology, 32(2): 229-237.

VRCIBRADIC, D., ROCHA, C. F. D., TELES, G. M. \& VAN SLUYS, M., 1998, Dieta conservativa em um ambiente sazonal: o caso de Mabuya frenata (Sauria: Scincidae) em Valinhos, SP. Anais do VIII Seminário Regional de Ecologia, 8: 857-867.

ZALUAR, H. L. T. \& ROCHA, C. F. D., 2000, Ecology of the wideforaging lizard Ameiva ameiva (Teiidae) in a sand dune habitat of Southeast Brazil: Ontogenetic, sexual and sexual trends in food habits, activity, thermal biology, and microhabitat use. Ciência e Cultura, 52(2): 101-107.

ZAR, J., 1999, Biostatistical analysis. Prentice Hall, New Jersey. 